\title{
THE INFLUENCE OF SOIL CULTIVATION AND FERTILIZATION ON THE YIELD AND PROTEIN CONTENT IN SEEDS OF COMMON PEA (PISUM SATIVUM L.)
}

\author{
EVA HANÁČKOVÁ*, EVA CANDRÁKOVÁ
}

Slovak University of Agriculture, Nitra

HANÁČKOVÁ, E. - CANDRÁKOVÁ, E.: The influence of soil cultivation and fertilization on the yield and protein content in seeds of common pea (Pisum sativum L.). Agriculture (Pol’nohospodárstvo), vol. 60, 2014, no. 3, pp. $98-107$.

\begin{abstract}
The aim of this study is to assess the effect of different soil tillage in the interaction with fertilization and the use of post-harvest residues on yield and protein content in pea seeds, variety Dunaj. The field experiment was established in years 2009-2011 on Experimental Base of the Slovak University of Agriculture in Dolná Malanta. There were evaluated based upon three soil tillage methods (B1 - conventional tillage, B2 - reduced tillage, B3 - minimal tillage $)$ and three treatments of fertilization $(0-$ unfertilized control, MF - balance fertilization by mineral fertilizers based on soil analysis and planned pea yield ( 3 t/ha), PHR - balance fertilization by mineral fertilizers + incorporation of post-harvest residues). Significantly higher seed yield was achieved at reduced tillage $(3.28 \mathrm{t} / \mathrm{ha})$ than conventional $(3.12 \mathrm{t} / \mathrm{ha})$ and minimized tillage $(3.08 \mathrm{t} / \mathrm{ha})$; however, most significantly, higher protein content in average of treatments was determined in conventional tillage
\end{abstract}

(23.38\%). Most significantly, negative linear correlation $\left(\mathrm{r}=-0.948^{+++}\right)$was determined between the yield and crude protein content in pea seeds. Fertilized treatments reached highly significant higher yields of common pea than unfertilized control. Compared with the control, average yield was higher by $10.3 \%-15.1 \%$. Significantly higher crude protein contents by $0.86 \%$ (PHR) and $1.27 \%$ (MF) were reached on unfertilized treatments than on fertilized one. The highest content of crude protein $(24.14 \%)$ and the highest production of it per hectare $(759 \mathrm{~kg} / \mathrm{ha})$ were determined in treatment with post harvest residues ploughed into soil. Over an average of 3 years, the highest profit (163.87 €/ha) and return (30.7\%) was achieved from the pea grown using fertilizing treatments (FM and PHR) at minimal soil tillage and systematic use of mineral fertilizers.

Key words: common pea, soil tillage, fertilization, yield, crude protein, pure protein

Common pea (Pisum sativum L.) is not only a substantial source of vegetable protein (mature seeds contain $22-28 \%$ of crude protein), but also positively affects soil fertility due to its valuable biological and agronomic properties. High forecrop value of common pea positively influences yields of follow crops (Nayyar et al. 2009) and reduces dependence on nitrogen fertilizers (Hanáčková \& Slamka 2011). Common pea utilizes significant proportion of phosphorus from less soluble compounds by the action of more aggressive root exudates and intensive sorption capacity of roots (Richter \& Hlušek 1999).

Despite the previously mentioned advantages, Slovakia is a minor producer of common pea. The risk of common pea growing lies in unstable yields. The main reason of this is the long period of generative organs differentiation, flowering, ripening and their high dependence on external environmental conditions (Doré et al. 1998). Decrease in producers' interests to grow pea are linked to the increased production costs, low selling price and often to the

doc. Ing. Eva Hanáčková, PhD. (*Corresponding author), Slovak University of Agriculture in Nitra, Faculty of Agrobiology and Food Resources, Tr. A. Hlinku 2, 94901 Nitra, Slovak Republic. E-mail: Eva.Hanackova@uniag.sk 
low prices of imported commodities (Ubrežiová et al. 2005).

Considering the nutrition and fertilization of common pea, it is necessary to respect its ability to function in symbiosis with nitrogen fixing bacteria. Kováčik (2001) reported that the proportion of nitrogen bound symbiotically or the total nitrogen content in the common pea biomass is $50 \%$; Jensen (1996) reported even more, that is $62 \%$. The dose of nitrogen fertilizer for pea growing depends on soil fertility and pea position in crop rotation. Vaněk et al. (2013) recommend fertilizing with nitrogen at a dose of $40 \mathrm{~kg} / \mathrm{ha}$ only on less fertile soils and in areas that do not provide good growing conditions for the pea plants and for atmospheric nitrogen fixation. According to ÚKSÚP (Central Control and Testing Agricultural Institute) data, doses of nitrogen for pea growing in the years 2005-2011 in Slovakia ranged from $36.4 \mathrm{~kg} / \mathrm{ha}$ (2009) to $62.3 \mathrm{~kg} / \mathrm{ha}(2008)$ and the average yield of pea seeds in that period was $1.91 \mathrm{t} / \mathrm{ha}$.

The aim of the study reported here is to assess the effect of different soil tillage in the interaction with fertilization and the use of post-harvest residues on yield and protein content in pea seeds.

\section{MATERIAL AND METHODS}

The field experiment with common pea (variety Dunaj) was established by randomized arrangement of experimental treatments in three repetitions on Experimental Base of the Slovak University of Agriculture in Dolná Malanta $\left(48^{\circ} 19^{\prime} \mathrm{N}, 18^{\circ} 09^{\prime} \mathrm{E}\right)$ from the year 2009-2011. The area belongs to the maize growing region, agro-climatically to very hot and dry subarea. Altitude of the site is $175-180 \mathrm{~m}$. The long-term average annual temperature of the site is $9.8^{\circ} \mathrm{C}$ and average rainfall is $540 \mathrm{~mm}$. Soil type was classified as Haplic Luvisol on proluvial sediments with loess. From the point of texture, it is loamy soil.

The 5-year crop rotation consisted of winter wheat (Triticum aestivum L.) - common pea ( $P i$ sum sativum L.) and mustard, which is used as cash crop - maize (Zea mays L.) - spring barley (Hordeum vulgare L.) - red clover (Trifolium pratense L.). Post-harvest residues of win- ter wheat forecrop were incorporated into soil amounting to $5 \mathrm{t} / \mathrm{ha} \mathrm{DM}$.

Three soil tillage methods were evaluated in the experiment: $\mathrm{B}_{1}$ - conventional tillage (ploughing by plough to the depth of $0.25 \mathrm{~m}$ ), $\mathrm{B}_{2}$ - reduced tillage (shallow ploughing by plough to the depth of $0.15 \mathrm{~m}$ ) and $\mathrm{B}_{3}-$ minimal tillage (offset disc ploughing to the depth of $0.1 \mathrm{~m}$ ) and three treatments of fertilization: 0 - control without fertilization, MF - balance fertilization by mineral fertilizers based on soil analysis and planned pea yield ( $3 \mathrm{t} / \mathrm{ha})$, PHR - balance fertilization by mineral fertilizers to planned yield with incorporation of post-harvest residues. Size of experimental plot of treatment represents $30 \mathrm{~m}^{2}$.

The content of available phosphorus was medium, potassium was good (Table 1) and soil reaction was slightly acidic. Nutrients were added on the base of balance method. Nitrogen at a dose of $30 \mathrm{~kg} / \mathrm{ha}$ was applied in the form of ammonium nitrate with lime, phosphorus $32 \mathrm{~kg} / \mathrm{ha}$ as $19 \%$ single superphosphate and potassium $37.5 \mathrm{~kg} / \mathrm{ha}$ in the form of $60 \%$ potassium salt.

Harvest of seed of pea was realized in full botanical maturity.

Weather conditions during the experimental period are shown in Figure 1.

Total nitrogen was determined according to the standard method of Kjeldahl in the pea seeds and protein nitrogen, according to Barstein (Javorský 1987). Total and protein nitrogen contents were multiplied by the coefficient of 6.25 and thus crude protein and pure protein contents were calculated.

Coefficient of natural effectiveness was calculated as follows: $\mathrm{K}_{\mathrm{NE}}=\Delta \mathrm{U} / \mathrm{D}_{\mathrm{N}}$, where

$\Delta \mathrm{U}=$ increment of seed yield per hectare due to

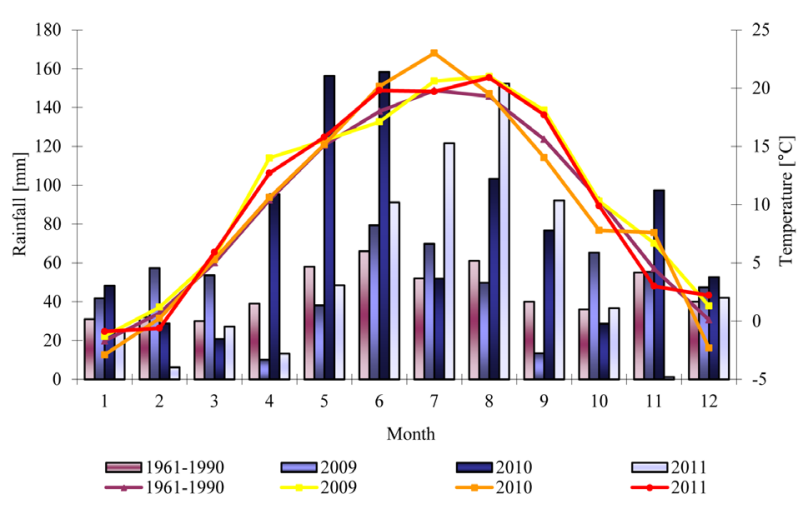

Figure 1. Weather conditions in years 2009-2011 
fertilization (expressed in $\mathrm{kg}$ ) in comparison to control unfertilized treatment;

$\mathrm{D}_{\mathrm{N}}=$ dose of nitrogen per hectare $[\mathrm{kg}]$ in respective treatments.

Coefficient of economical effectiveness was calculated as follows: $\mathrm{K}_{\mathrm{EE}}=\Delta \mathrm{U} / \mathrm{D}_{\mathrm{N}}$, where:

$\Delta \mathrm{U}=$ increment of seed yield per hectare due to fertilization (expressed in $€$ ) in comparison to control unfertilized treatment;

$\mathrm{D}_{\mathrm{N}}=$ dose of nitrogen per hectare (expressed in $€)$ in respective treatments.

Profit was calculated as follows: Profit $[€ / \mathrm{ha}]=\Delta U$ $[€ /$ ha $]-D_{\mathrm{N}}[€ / \mathrm{ha}]$

Profit and return from pea cultivation were calculated on the basis of invested costs and acquired total production revenue. Profit was calculated as a difference between costs and revenue; and return as a ratio of profit to invested costs. Total costs also included cost for soil tillage (Normativy pro zemědelskou a potravinařskou výrorobu AGroCon- sult [online]), cost for seed, pesticides and fertilizers purchase. Average selling price of pea represented $214.66 € / t$ during the years 2009-2011 (Jamborová 2012).

Obtained results were evaluated by statistical software Statgraphics Plus. Evaluation of importance of individual factors on studied parameters was done by multifactorial analysis of variance (ANOVA, Statistica 5). Differences between variants were assessed by LSD test with a minimum significance level $P \leq 0.05$. Correlation analysis was used for detection of relations between chemical properties.

\section{RESULTS AND DISCUSSION}

All examined experimental factors showed statistically highly significant effect on pea seed yield and content of protein in it (Table 3). The yield of

T

Content of available nutrients in soil before experiment establishment (Rates of nutrients were $30 \mathrm{~kg} \mathrm{~N} / \mathrm{ha}, 32 \mathrm{~kg} \mathrm{P} / \mathrm{ha}, 37.5 \mathrm{~kg} \mathrm{~K} / \mathrm{ha}$ )

\begin{tabular}{|c|c|c|c|c|c|}
\hline Year & \multicolumn{2}{|c|}{ Treatment } & $\begin{array}{l}\text { Content } \mathrm{N}_{\text {an }} \\
{[\mathrm{mg} / \mathrm{kg}]}\end{array}$ & $\begin{array}{c}\text { Content P } \\
{[\mathrm{mg} / \mathrm{kg}]}\end{array}$ & $\begin{array}{c}\text { Content K } \\
{[\mathrm{mg} / \mathrm{kg}]}\end{array}$ \\
\hline \multirow{3}{*}{ ஓे } & $\mathrm{B}_{1}$ & $\begin{array}{l}\text { MF } \\
\text { PHR }\end{array}$ & $\begin{array}{l}7.4 \\
6.8\end{array}$ & $\begin{array}{l}79 \\
74\end{array}$ & $\begin{array}{l}260 \\
245\end{array}$ \\
\hline & $\mathrm{B}_{2}$ & MF & 7.0 & 84 & 270 \\
\hline & $\mathrm{B}_{3}$ & $\begin{array}{c}\text { MF } \\
\text { PHR }\end{array}$ & $\begin{array}{l}8.2 \\
6.5\end{array}$ & $\begin{array}{l}81 \\
76\end{array}$ & $\begin{array}{l}277 \\
265\end{array}$ \\
\hline \multirow{3}{*}{$\stackrel{\circ}{\stackrel{1}{\circ}}$} & $\mathrm{B}_{1}$ & $\begin{array}{l}\text { MF } \\
\text { PHR }\end{array}$ & $\begin{array}{l}8.6 \\
8.0\end{array}$ & $\begin{array}{l}82 \\
78\end{array}$ & $\begin{array}{l}265 \\
250\end{array}$ \\
\hline & $\mathrm{B}_{2}$ & $\begin{array}{l}\text { MF } \\
\text { PHR }\end{array}$ & $\begin{array}{l}7.9 \\
7.4\end{array}$ & $\begin{array}{l}80 \\
76\end{array}$ & $\begin{array}{l}254 \\
248\end{array}$ \\
\hline & $\mathrm{B}_{3}$ & $\begin{array}{l}\text { MF } \\
\text { PHR }\end{array}$ & $\begin{array}{l}8.2 \\
7.5\end{array}$ & $\begin{array}{l}79 \\
77\end{array}$ & $\begin{array}{l}275 \\
260\end{array}$ \\
\hline \multirow{3}{*}{ ন } & $\mathrm{B}_{1}$ & $\begin{array}{l}\text { MF } \\
\text { PHR }\end{array}$ & $\begin{array}{l}8.0 \\
7.4\end{array}$ & $\begin{array}{l}79 \\
75\end{array}$ & $\begin{array}{l}261 \\
255\end{array}$ \\
\hline & $\mathrm{B}_{2}$ & $\begin{array}{l}\text { MF } \\
\text { PHR }\end{array}$ & $\begin{array}{l}8.2 \\
7.1\end{array}$ & $\begin{array}{l}80 \\
76\end{array}$ & $\begin{array}{l}264 \\
257\end{array}$ \\
\hline & $\mathrm{B}_{3}$ & $\begin{array}{l}\text { MF } \\
\text { PHR }\end{array}$ & $\begin{array}{l}8.5 \\
8.0\end{array}$ & $\begin{array}{l}84 \\
78\end{array}$ & $\begin{array}{l}274 \\
270\end{array}$ \\
\hline
\end{tabular}

$\mathrm{B}_{1}-$ conventional tillage, $\mathrm{B}_{2}-$ reduced tillage, $\mathrm{B}_{3}-$ minimal tillage, MF - mineral fertilizers, PHR - mineral fertilizers + post-harvest residues 
pea seeds in years 2009-2011 was influenced by weather conditions, the method of soil cultivation and fertilization. On the average of variants, grain yield of $3.16 \mathrm{t} / \mathrm{ha}$ was achieved in small plots experiment.

Reduced tillage was the most appropriate method of soil tillage for achieving the highest yield of common pea seeds $(3.28 \mathrm{t} / \mathrm{ha})$ on the average of fertilization treatments in years 2009-2011. This yield was most significantly higher than that of conventional tillage and use of disk tools (Table 4). Ondrišík (2013) stated that reduced tillage compared with conventional leads to increased microbial ac- tivity and biomass. The lowest yield was achieved in treatment with minimized tillage, which is in accordance with our results of pea tillage reached in years 2005-2007. Nevertheless, in that period, not significantly higher yield was reached with conventional than reduced tillage (Candráková \& Hanáčková 2013).

Most significantly higher yields of common pea were reached with fertilized treatments than with unfertilized control (Table 6). The positive effect of fertilization on yield of common pea was reported by several authors (Bojňanská \& Vološinová 2005; Šariková 2005). Compared to control, higher avera-

T a b 1 e 2

Yield, content and production of protein in common pea seed

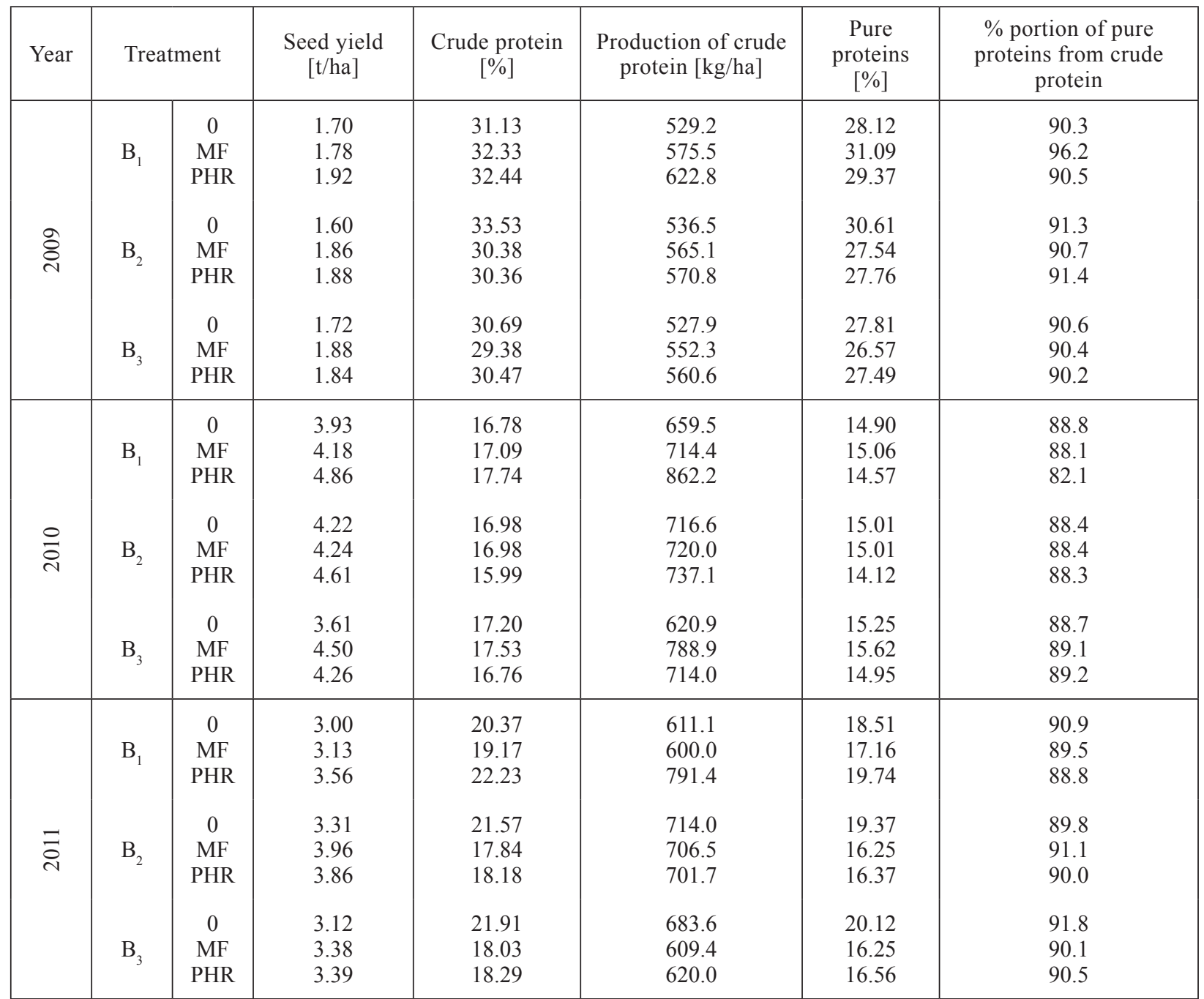

0 - Unfertilized control treatment

Abbreviations see Table 1 
ge yield (by $10.3 \%$ to $15.1 \%$ ) was achieved on the fertilized treatments. The highest yields in average of three experimental years and soil tillage methods were reached by treating with incorporated crop residues despite the addition of the same nitrogen doses $(30 \mathrm{~kg} / \mathrm{ha})$ on fertilized treatments.

The utilization of mineral fertilizers in yield formation tends to be significantly affected by weather conditions (Jamriška et al. 2005), as was also confirmed by our results. Common pea, more evidently, responded to fertilization in wet year 2010, when the yield of seeds was on an average higher by $2.47 \mathrm{t} / \mathrm{ha}$ than in 2009, when the lack of rainfall in the spring occurred.

Considerable differences in achieved yields were caused not only by the harvest year, but also by the method of soil tillage in the interaction with fertilization. The highest average yield of pea seeds was achieved under mouldboard ploughing $\left(\mathrm{B}_{1}, \mathrm{~B}_{2}\right)$ in the treatment with incorporated post-harvest resi-

T $\quad$ a $\quad$ b 1 l e $\quad 3$

Mean squares from analysis of evaluated traits: common pea

\begin{tabular}{|l|c|c|c|c|c|}
\hline Source & $d f$ & Seeds yield & Crude protein & $\begin{array}{c}\text { Production of } \\
\text { crude protein }\end{array}$ & Pure protein \\
\hline A: year & 2 & $42.476^{++}$ & $1529.61^{++}$ & $192704.0^{++}$ & $1374.54^{++}$ \\
B: soil tillage & 2 & $0.317^{++}$ & $7.75^{++}$ & $9319.1^{++}$ & $5.91^{++}$ \\
C: fertilization & 2 & $1.370^{++}$ & $11.32^{++}$ & $28531.0^{++}$ & $8.93^{++}$ \\
AB & 4 & $0.218^{++}$ & $2.86^{+}$ & $3394.6^{++}$ & $4.70^{++}$ \\
AC & 4 & $0.117^{++}$ & $5.65^{++}$ & $7165.1^{++}$ & $5.50^{++}$ \\
BC & 4 & $0.148^{++}$ & $9.24^{++}$ & $19764.0^{++}$ & $6.55^{++}$ \\
Residual & 62 & 0.018 & 0.54 & 670.0 & 0.63 \\
Total & 80 & & & & \\
\hline
\end{tabular}

${ }^{++} P \leq 0.01 ;{ }^{+} P \leq 0.05 ; d f-$ Degree of freedom

$\mathrm{T}$ a

Testing of the differences between the levels of examined factors

\begin{tabular}{|c|c|c|c|c|}
\hline Factor & $\begin{array}{l}\text { Seed yield } \\
{[\mathrm{t} / \mathrm{ha}]}\end{array}$ & $\begin{array}{l}\text { Crude protein } \\
\text { content }[\%]\end{array}$ & $\begin{array}{c}\text { Production of } \\
\text { crude protein } \\
{[\mathrm{kg} / \mathrm{ha}]}\end{array}$ & $\begin{array}{c}\text { Pure proteins } \\
\text { content }[\%]\end{array}$ \\
\hline \multicolumn{5}{|c|}{ Year } \\
\hline $\begin{array}{l}2009 \\
2010 \\
2011\end{array}$ & $\begin{array}{l}1.80^{\mathrm{a}} \\
4.27^{\mathrm{c}} \\
3.41^{\mathrm{b}}\end{array}$ & $\begin{array}{l}31.19^{\mathrm{c}} \\
16.99^{\mathrm{a}} \\
19.73^{\mathrm{b}}\end{array}$ & $\begin{array}{l}560.08^{\mathrm{a}} \\
725.96^{\mathrm{c}} \\
670.86^{\mathrm{b}}\end{array}$ & $\begin{array}{l}28.49^{\mathrm{c}} \\
14.94^{\mathrm{a}} \\
17.81^{\mathrm{b}}\end{array}$ \\
\hline \multicolumn{5}{|c|}{ Soil tillage } \\
\hline $\begin{array}{l}\text { Conventional }\left(\mathrm{B}_{1}\right) \\
\text { Reduced }\left(\mathrm{B}_{2}\right) \\
\text { Minimal }\left(\mathrm{B}_{3}\right)\end{array}$ & $\begin{array}{l}3.12^{\mathrm{a}} \\
3.28^{\mathrm{b}} \\
3.08^{\mathrm{a}}\end{array}$ & $\begin{array}{l}23.25^{\mathrm{b}} \\
22.40^{\mathrm{a}} \\
22.25^{\mathrm{a}}\end{array}$ & $\begin{array}{l}662.90^{\mathrm{b}} \\
663.14^{\mathrm{b}} \\
630.84^{\mathrm{a}}\end{array}$ & $\begin{array}{l}20.95^{\mathrm{b}} \\
20.23^{\mathrm{a}} \\
20.07^{\mathrm{a}}\end{array}$ \\
\hline \multicolumn{5}{|c|}{ Fertilization } \\
\hline $\begin{array}{l}\text { Control }(0) \\
\text { Mineral fertilizers }(\mathrm{MF}) \\
\text { Mineral fertilizers }+ \text { post harvest residues (PHR) }\end{array}$ & $\begin{array}{l}2.91^{\mathrm{a}} \\
3.21^{\mathrm{b}} \\
3.35^{\mathrm{c}}\end{array}$ & $\begin{array}{l}23.35^{\mathrm{b}} \\
22.08^{\mathrm{a}} \\
22.48^{\mathrm{a}}\end{array}$ & $\begin{array}{l}622.14^{a} \\
648.01^{b} \\
686.73^{c}\end{array}$ & $\begin{array}{l}21.07^{\mathrm{b}} \\
20.06^{\mathrm{a}} \\
20.10^{\mathrm{a}}\end{array}$ \\
\hline
\end{tabular}

$L S D=$ least significant difference

$L S D$ values are valid for all examined experimental factors

Different letters within the same column of each trait indicate significant differences at $P \leq 0.05$ 
dues $(3.45 \mathrm{t} / \mathrm{ha})$, and the lowest yield at unfertilized treatment with minimized tillage $(2.82 \mathrm{t} / \mathrm{ha})$.

Obtained results confirmed the fact that the yield is most significantly affected by weather conditions mainly in crops with a short growing season, which is also characteristic for common pea. During the evaluated period, the most significantly lowest average yield (1.80 t/ha) was reached in year 2009. Very humid February and March had shifted the sowing term to the beginning of April, characterized as very warm and dry that negatively influenced the number of plants per unit area and their short stature.

The highest yield of common pea ( $4.27 \mathrm{t} / \mathrm{ha})$ was achieved in year 2010 despite the large weather fluctuations. In spite of very wet April, May and June, very warm June and exceptionally hot July, the crop was complete and healthy. The yield of pea seeds was most significantly higher than in years 2009 and 2011 (Table 4).

$\mathrm{T}$ a $\quad$ b 1 e e 5

Testing of the differences between the levels of soil tillage

\begin{tabular}{|c|c|c|c|c|c|}
\hline Year & $\begin{array}{c}\text { Soil } \\
\text { tillage }\end{array}$ & $\begin{array}{c}\text { Seed yield } \\
{[\mathrm{t} / \mathrm{ha}]}\end{array}$ & $\begin{array}{c}\text { Crude protein content } \\
{[\%]}\end{array}$ & $\begin{array}{c}\text { Production } \\
\text { of crude protein } \\
{[\mathrm{kg} / \mathrm{ha}]}\end{array}$ & $\begin{array}{c}\text { Pure } \\
\text { proteins content } \\
{[\%]}\end{array}$ \\
\hline \multirow{2}{*}{2009} & $\mathrm{~B}_{1}$ & $1.80^{\mathrm{a}}$ & $31.96^{\mathrm{b}}$ & $575.83^{\mathrm{c}}$ & $29.52^{\mathrm{c}}$ \\
& $\mathrm{B}_{2}$ & $1.78^{\mathrm{a}}$ & $31.42^{\mathrm{b}}$ & $557.47^{\mathrm{b}}$ & $28.63^{\mathrm{b}}$ \\
& $\mathrm{B}_{3}$ & $1.81^{\mathrm{a}}$ & $30.18^{\mathrm{a}}$ & $546.93^{\mathrm{a}}$ & $14.29^{\mathrm{a}}$ \\
\hline \multirow{2}{*}{2010} & $\mathrm{~B}_{1}$ & $4.32^{\mathrm{b}}$ & $17.20^{\mathrm{a}}$ & $745.37^{\mathrm{c}}$ & $14.71^{\mathrm{a}}$ \\
& $\mathrm{B}_{2}$ & $4.35^{\mathrm{b}}$ & $16.65^{\mathrm{a}}$ & $724.57^{\mathrm{b}}$ & $15.27^{\mathrm{a}}$ \\
\hline \multirow{3}{*}{2011} & $\mathrm{~B}_{3}$ & $4.12^{\mathrm{a}}$ & $17.16^{\mathrm{a}}$ & $707.93^{\mathrm{a}}$ & $18.47^{\mathrm{b}}$ \\
& $\mathrm{B}_{1}$ & $3.23^{\mathrm{a}}$ & $20.59^{\mathrm{b}}$ & $667.50^{\mathrm{b}}$ & $17.33^{\mathrm{a}}$ \\
& $\mathrm{B}_{2}$ & $3.71^{\mathrm{b}}$ & $19.19^{\mathrm{a}}$ & $707.40^{\mathrm{c}}$ & $17.64^{\mathrm{a}}$ \\
\hline
\end{tabular}

Abbreviations see Table 1

Seeds yield: $L S D_{0.05}=0.0184$; Crude protein: $L S D_{0.05}=0.5360$; Production of crude protein: $L S D_{0.05}=14.0821$; Pure proteins: $L S D_{0.05}=0.6310$;

$L S D$ values are valid for all examined experimental factors

Different letters within the same column of each trait indicate significant differences at $P \leq 0.05$

$$
\mathrm{T} \text { a }
$$

Testing of the differences between the levels of fertilization

\begin{tabular}{|l|c|c|c|c|c|}
\hline Year & Fertilization & $\begin{array}{c}\text { Seed yield } \\
{[\mathrm{t} / \mathrm{ha}]}\end{array}$ & $\begin{array}{c}\text { Crude protein content } \\
{[\%]}\end{array}$ & $\begin{array}{c}\text { Production } \\
\text { of crude protein } \\
{[\mathrm{kg} / \mathrm{ha}]}\end{array}$ & $\begin{array}{c}\text { Pure } \\
\text { proteins content } \\
{[\%]}\end{array}$ \\
\hline \multirow{2}{*}{2009} & 0 & $1.67^{\mathrm{a}}$ & $31.78^{\mathrm{b}}$ & $531.20^{\mathrm{a}}$ & $28.84^{\mathrm{a}}$ \\
& $\mathrm{MF}$ & $1.84^{\mathrm{b}}$ & $30.69^{\mathrm{a}}$ & $564.30^{\mathrm{b}}$ & $28.40^{\mathrm{a}}$ \\
\hline \multirow{3}{*}{2010} & $1.88^{\mathrm{b}}$ & $31.09^{\mathrm{ab}}$ & $584.73^{\mathrm{c}}$ & $28.20^{\mathrm{a}}$ \\
\hline \multirow{3}{*}{2011} & PHR & $3.92^{\mathrm{a}}$ & $16.98^{\mathrm{a}}$ & $665.67^{\mathrm{a}}$ & $15.05^{\mathrm{a}}$ \\
& PHR & $4.30^{\mathrm{b}}$ & $17.20^{\mathrm{a}}$ & $741.10^{\mathrm{b}}$ & $15.23^{\mathrm{a}}$ \\
& 0 & $4.57^{\mathrm{c}}$ & $16.83^{\mathrm{a}}$ & $771.10^{\mathrm{c}}$ & $14.54^{\mathrm{a}}$ \\
\hline
\end{tabular}

0 - Unfertilized control treatment

Abbreviations see Table 1

Seeds yield: $L S D_{0.05}=0.0184$; Crude protein: $L S D_{0.05}=0.5360$; Production of crude protein: $L S D_{0.05}=14.0821$; Pure proteins: $L S D_{0.05}=0.6310$;

$L S D$ values are valid for all examined experimental factors

Different letters within the same column of each trait indicate significant differences at $P \leq 0.05$ 
The second highest yield (3.41 t/ha) was reached in year 2011. Such yield, higher by $0.86 \mathrm{t} / \mathrm{ha}$ compared to the national average, represented an increase of yield by $33.7 \%$.

Common pea is exceptionally sensitive to temperature and moisture conditions during so-called critical periods (Mathe-Gaspar et al. 2005). Pea has the maximum demand for moisture during the period of maximum dry matter formation, that is, not only during flowering, but also after flowering. Excessive rainfall during the ripening period adversely affects the quality of seeds and prolongs the vegetation (Špaldon et al. 1982).
Protein, for its nutritional and feeding value, is the most important of all substances involved in pea seeds. Protein content (crude protein) in pea seeds in years 2009-2011 was significantly influenced by harvest year, method of soil tillage and fertilization (Table 5, 6). The average content was $22.65 \%$. Burstin et al. (2011) state protein content in pea in the range of $15.8-32.1 \%$. They stated that protein content varied depending on the cultivar, location and harvest year.

The crude protein content was most significantly affected by the harvest year that is in accordance with the results of other authors (Bojňanská \&

T a b 1 e 7

Natural and economical effectiveness of common pea nitrogen fertilization (Fertilization cost $33.3 € /$ ha)

\begin{tabular}{|c|c|c|c|c|c|c|}
\hline \multirow{2}{*}{\multicolumn{2}{|c|}{$\begin{array}{l}\text { Treatment } \\
\text { tillage/fertilization }\end{array}$}} & \multicolumn{2}{|c|}{ Increment of seed yield } & \multirow{2}{*}{$\mathrm{K}_{\mathrm{NE}}$} & \multirow{2}{*}{$\mathrm{K}_{\mathrm{EE}}$} & \multirow{2}{*}{$\begin{array}{l}\text { Profit } \\
{[€ / \text { ha }]}\end{array}$} \\
\hline & & {$[\mathrm{kg} / \mathrm{ha}]$} & {$[€ /$ ha $]$} & & & \\
\hline $\begin{array}{c}\text { Conventional } \\
\left(\mathrm{B}_{1}\right)\end{array}$ & $\begin{array}{l}\text { MF } \\
\text { PHR }\end{array}$ & $\begin{array}{l}160 \\
395\end{array}$ & $\begin{array}{l}31.72 \\
78.31\end{array}$ & $\begin{array}{c}5.33 \\
13.17\end{array}$ & $\begin{array}{l}0.95 \\
2.35\end{array}$ & $\begin{array}{l}-1.58 \\
45.01\end{array}$ \\
\hline $\begin{array}{l}\text { Reduced } \\
\qquad\left(\mathrm{B}_{2}\right)\end{array}$ & $\begin{array}{l}\text { MF } \\
\text { PHR }\end{array}$ & $\begin{array}{l}285 \\
360\end{array}$ & $\begin{array}{l}56.50 \\
71.37\end{array}$ & $\begin{array}{c}9.50 \\
12.00\end{array}$ & $\begin{array}{l}1.70 \\
2.14\end{array}$ & $\begin{array}{l}23.20 \\
38.07\end{array}$ \\
\hline $\begin{array}{l}\text { Minimal } \\
\left(\mathrm{B}_{3}\right)\end{array}$ & $\begin{array}{l}\text { MF } \\
\text { PHR }\end{array}$ & $\begin{array}{l}295 \\
370\end{array}$ & $\begin{array}{l}58.48 \\
73.35\end{array}$ & $\begin{array}{c}9.83 \\
12.33\end{array}$ & $\begin{array}{l}1.76 \\
2.20\end{array}$ & $\begin{array}{l}25.18 \\
40.05\end{array}$ \\
\hline
\end{tabular}

Abbreviations see Table 1

$\mathrm{K}_{\mathrm{NE}}-$ coefficient of natural effectiveness; $\mathrm{K}_{\mathrm{EE}}-$ coefficient of economical effectiveness

T a b 1 e 8

Economical evaluation of pea growing (average years 2009-2011)

\begin{tabular}{|c|c|c|c|c|c|c|}
\hline \multicolumn{2}{|c|}{ Treatment } & $\begin{array}{c}\text { Seed yield } \\
{[\mathrm{t} / \mathrm{ha}]}\end{array}$ & $\begin{array}{l}\text { Cost } \\
{[€ / \text { ha] }}\end{array}$ & $\begin{array}{c}\text { Revenue } \\
{[€ / \text { ha] }}\end{array}$ & $\begin{array}{l}\text { Profit } \\
{[€ / \text { ha }]}\end{array}$ & $\begin{array}{c}\text { Return } \\
{[\%]}\end{array}$ \\
\hline \multirow{3}{*}{$\mathrm{B}_{1}$} & 0 & 2.88 & 416.30 & 618.22 & 201.92 & 48.5 \\
\hline & MF & 3.03 & 590.30 & 650.42 & 60.12 & 10.2 \\
\hline & PHR & 3.45 & 590.30 & 740.58 & 150.28 & 25.5 \\
\hline \multirow{3}{*}{$B_{2}$} & 0 & 3.04 & 410.32 & 652.57 & 242.25 & 59.0 \\
\hline & MF & 3.35 & 584.32 & 719.11 & 134.79 & 23.1 \\
\hline & PHR & 3.45 & 584.32 & 740.58 & 156.26 & 26.7 \\
\hline \multirow{3}{*}{$\mathrm{B}_{3}$} & 0 & 2.82 & 359.78 & 605.34 & 245.56 & 68.3 \\
\hline & MF & 3.25 & 533.78 & 697.65 & 163.87 & 30.7 \\
\hline & PHR & 3.16 & 533.78 & 678.33 & 144.55 & 27.1 \\
\hline
\end{tabular}

0 - Unfertilized control treatment

Abbreviations see Table 1 
Frančáková 2001). The highest crude protein content was determined in year $2009(31.16 \%)$ when the lowest pea seeds yield was reached; on the contrary, the lowest crude protein content $(17.09 \%)$ was recorded in the year 2010, when the yield was the highest (Table 2). Obtained results confirmed negative, highly significant correlation $\left(\mathrm{r}=-0.948^{+++}\right)$ between yield and crude protein content in pea seeds.

Negative correlation was probably caused by enlarging the ratio of seeds yield to the total aboveground phytomass yield, resulting in less nitrogen coning per the unit weight of seeds (Hanáčková et al. 2010).

The protein content in pea seeds was influenced by method of soil tillage as well. Most significantly, higher crude protein content was determined in treatment with conventional tillage $(23.38 \%)$ than in reduced $(22.34 \%)$ and minimized tillage $(22.22 \%)$.

Significantly higher crude protein contents were reached on unfertilized treatments than on fertilized by $0.86 \%$ (PHR) and by $1.27 \%(\mathrm{MF})$, respectively. Gyori and Bocz (1991) reported higher nitrogen content in pea seeds due to fertilization only in dry years. The highest crude protein content was found in treatment with deep incorporation of crop residues ( $\mathrm{B}_{1}$-PHR), and the lowest in treatment with shallower incorporation $\left(\mathrm{B}_{2}-\mathrm{MF}\right)$.

The production of crude protein is derived from its content in pea seeds and crop yield. The highest protein production $(729 \mathrm{~kg} / \mathrm{ha})$ was reached in year 2010, when the highest seeds yield was achieved. In the year 2009, with the lowest seeds yield, the protein production was lower by $169 \mathrm{~kg} / \mathrm{ha}$ compared with 2010. Conventional tillage and treatment with incorporated post-harvest residues have been proven suitable in terms of protein production.

Results shown in Table 2 provide information about the total content of crude protein, and socalled pure protein (according to protein nitrogen values) in pea seeds. Pure protein content increased highly significantly with the increase of crude protein content $\left(r=0.9975^{+++}\right)$. In different fertilization treatments, content of pure protein ranged from $20.06 \%$ (MF) to $21.08 \%$ (0). The average proportion of pure from crude protein was $89.8 \%$.

Table 7 shows that on the average of 3 experimental years, both methods of soil tillage as well as way of fertilization influenced utilization of nitrogen and effectiveness of nitrogen fertilization. When only mineral fertilizers (treatment MF) were applied, the highest increment of pea seed was achieved under minimal soil tillage $\left(\mathrm{B}_{3}\right)$. In this case, coefficient of natural effectiveness $\left(\mathrm{K}_{\mathrm{NE}}\right)$ achieved the value of 9.83 that is $9.83 \mathrm{~kg}$ of seed was created per $1 \mathrm{~kg}$ of applied nitrogen. The lowest $\mathrm{K}_{\mathrm{NE}}$ value (5.33) was reached under mineral fertilization and conventional soil tillage.

Combined fertilization with mineral fertilizers and post-harvest residues incorporation (MF+PHR) showed stimulation effect on nitrogen utilization with all methods of soil tillage. The evidence of this is the fact that $\mathrm{K}_{\mathrm{NE}}$ was increasing in comparison to the treatments fertilized solo with mineral fertilizers. The biggest effect under this combination of fertilization was achieved by conventional soil tillage $\left(\mathrm{K}_{\mathrm{NE}}=13.17\right)$ and the lowest one by reduced soil tillage $\left(\mathrm{K}_{\mathrm{NE}}=12.0\right)$.

With coefficient of economical effectiveness $\left(\mathrm{K}_{\mathrm{EE}}\right)$ as well as with profit, the same trends as with coefficient of natural effectiveness were found out (Table 7).

Economic evaluation of pea growing is stated in Table 8. When we assess fertilization treatments in combination with applied methods of soil tillage, then both the highest profit and return of pea growing were achieved by unfertilized treatment with all methods of soil tillage, respectively. However, pea growing without the use of mineral and organic fertilization is not acceptable from the viewpoint of sustainable farming system. Thus, when we take into account only fertilized treatments (MF and PHR), there were gains of highest profit $(163.87 € /$ ha) and return $(30.7 \%)$ from pea cultivation with minimal soil tillage in combination with mineral fertilization on the average of three years (Table 8).

\section{CONCLUSIONS}

Yield and protein content in pea seeds were significantly affected by harvest year, tillage method and fertilization.

Significantly higher yield of seeds was reached by using reduced tillage than conventional and minimized. However, most significantly higher protein content in average of treatments was determined in 
conventional tillage. On the average of three experimental years and three treatments of fertilization, the highest production of protein per hectare was achieved under reduced and conventional tillage (no significant difference). In comparison with minimal soil tillage, the difference in protein production was statistically significant. Most significantly, negative linear correlation was found between the yield and crude protein content in pea seeds.

Fertilized treatments provided most significantly higher yields of common pea seed than unfertilized control. Compared to the control, the average yield was higher by $10.3-15.1 \%$.

On average, the crude protein content was significantly higher by $0.86 \%$ (PHR) to $1.27 \%$ (MF) on unfertilized control treatment than on fertilized treatments. The highest content of crude protein was found through treatment with post harvest residues ploughed into soil $\left(\mathrm{B}_{1}-\mathrm{PHR}=24.14 \%\right)$. Total production of protein by this treatment ( $\left.\mathrm{B}_{1}-\mathrm{PHR}\right)$ achieved $759 \mathrm{~kg} / \mathrm{ha}$ that represents significantly higher protein production in comparison to unfertilized conventional treatment $\left(\mathrm{B}_{1}-0\right)$ as well as rationally fertilized conventional treatment $\left(\mathrm{B}_{1}-\mathrm{MF}\right)$.

Incorporation of precrop post-harvest residues into soil together with mineral fertilization increased utilization of nitrogen under all methods of soil tillage, resulting in increased creation of pea seeds per $1 \mathrm{~kg}$ of applied nitrogen $\left(\mathrm{K}_{\mathrm{NE}}\right)$. The best results were achieved when mineral fertilizers together with post-harvest residues were ploughed down into the soil within the framework of conventional soil tillage $\left(\mathrm{K}_{\mathrm{NE}}=13.17 ; \mathrm{K}_{\mathrm{EE}}=2.35\right.$ and profit $\left.45 € / \mathrm{ha}\right)$. From the economic standpoint (considering the cost of the entire growth technology and the total production revenue), this treatment reached a profit of $150.28 € /$ ha and returns of $25.5 \%$ on pea cultivation. The highest profit (163.87 €/ha) and return (30.7\%) was, over an average of three years, achieved in the pea cultivation using fertilizing treatments (FM and PHR), at minimal soil tillage and systematic use of mineral fertilizers.

Acknowledgements. The paper was supported by project VEGA 1/0816/11 "The production process of field crops under different tillage systems, application of fertilizers and plant residues, with regard to maintenance and improvement of soil fertility."

\section{REFERENCES}

BOJŇANSKÁ, T. - FRANČÁKOVÁ, H. 2001. The influence of growing systems on utility value of Pisum sativum L. In Acta fytotechnica et zootechnica, vol. 4, Special Number, pp. 214-216.

BOJŇANSKÁ, T. - VOLOŠINOVÁ, V. 2005. Dependence of pea quality on growing system. In Agriculture (Pol'nohospodárstvo), vol. 51, no. 10, pp. 539-547.

BURSTIN, J. - GALLARDO, K. - MIR, R.R. et al. 2011. Improving protein content and nutrition quality. In PRATAP, A. - KUMAR, J. (Eds): Biology and Breeding of Food Legumes. CAB International, pp. 314-328. ISBN 9781845937669.

DORÉ, T. - MEYNARD, J. M. - SEBILLOTTE, M. 1998. The role of grain number, nitrogen nutrition and stem number in limiting pea crop (Pisum sativum) yields under agricultural conditions. In European Journal of Agronomy, vol. 8, no. 1-2, pp. 29-37.

GYORI, Z. - BOCZ, E. 1991. Effect of fertilization and irrigation on the mineral element content and amino-acid-composition of peas. 1. Nitrogen-content and amino-acid-composition. In Novenytermeles, vol. 40, no. 6, pp. 509-519.

HANÁČKOVÁ, E. - CANDRÁKOVÁ, E. - MACÁK, M. 2010. Udržatelný technologický systém pestovania hrachu siateho (Pisum sativum L.) [Technological system for sustainable growing of common peas]. Nitra : SPU, 162 p. ISBN 978-80-552-0345-4.

HANÁČKOVÁ, E. - SLAMKA, P. 2011. Production process of winter wheat (Triticum aestivum L.) under different soil cultivation and fertilization. In Research Journal of Agricultural Science, vol. 43, no. 1, pp. 56-61.

CANDRÁKOVÁ, E. - HANÁČKOVÁ, E. 2013. Vplyv vybraných faktorov na úrodu a obsah bielkovín v semenách hrachu siateho (Pisum sativum L.) [Effect of selected factors on the yield and content of protein in seeds of common pea (Pisum sativum L.)] In Agrochémia, vol. XVII (53), no. 3, pp. 18-23.

JAMBOROVÁ, M. 2012. Strukoviny. Situačná a výhl'adová správa k 30.6.2012 (Legumes: Situation and prospective report dated on the 30th of June, 2012. Bratislava: VÚEPP, vol. $X X, 2012$, no. 1, pp. 18.

JAMRIŠKA, P. - RÜCKSCHLOSS, L. - HAŠANA, R. KUBIŠOVÁ, A. 2005. Účinok hnojenia pšenice letnej f. ozimnej na úrodu zrna v odlišných poveternostných podmienkach [Effect of winter wheat fertilization on grain yield in different weather conditions]. In Agriculture (Pol'nohospodárstvo), vol. 51, no. 10, pp. 513-520.

JENSEN, E.S. 1996. Grain yield, symbiotic $\mathrm{N}_{2}$ fixation and interspecific competition for inorganic $\mathrm{N}$ in pea - barley intercrops. In Plant Soil, vol. 182, pp. 25-38.

JAVORSKÝ, P. 1987. Chemické rozbory v zemědělských laboratorích [Chemical analysis at agricultural laboratories]. Praha: MZV [Ministry of Agric. and Food of Czechoslovakia], $287 \mathrm{p}$.

KOVÁČIK, P. 2001. Metodika bilancie živin v pôdach ekologicky hospodáriacich podnikov [Methodolo- 
gy of nutrient balance in organically farmed soils] Nitra : SPU, 44 p. ISBN 80-7137-957-3.

MATHE-GASPAR, G. - FODOR, N. - POKOVAI, K. KOVACS, G.J. 2005. Crop modeling as a tool to separate the influence of the soil and weather on crop yields. In Physics and Chemistry of the Earth, vol. 30 , no. $1-3$, pp. $165-169$.

NAYYAR, A. - HAMEL, CH. - GOSSEN, B.D. - HANSON, K. - GERMIDA, J. 2009. Soil microbial quality associated with yield reduction in continuous-pea. In Applied Soil Ecology, vol. 43, pp. 115-121.

NORMATÍVY PRO ZEMĚDĚLSKOU A POTRAVINAŘSKOU VÝROBU [Standards for agricultural and food production] AGROCONSULT [online]. Aktualizované k 31.7.2014 [cit. 2013-10-30]. Available at http://www.agronormativy.cz/docs/4050002_rslt. html.

ONDRIŠÍK, P. 2013. Dynamika anorganického dusí$k a$ v pôde a možnosti jej regulácie [The dynamics of inorganic nitrogen in soil and possibilities of its regulation]. Nitra : SPU, 97 p. ISBN 978-80-5521032-2.

RICHTER, R. - HLUŠEK, J. 1999. Výživa a hnojení rost- lin. I. obecná část [Plants nutrition and fertilization. I. general part]. Brno : MZLU, 177 p. ISBN 80-7157138-5.

ŠARIKOVÁ, D. 2005. Vplyv hnojenia na úrodu a úrodotvorné prvky sledovaných odrôd hrachu siateho [Effect of fertilization on yield and yield components of common pea varieties]. In Zbornik vedeckých prác 21. Michalovce : VÚRV-ÚA, pp. 31-39. ISBN 80-88790-44

ŠPALDON, E. - ANDRAŠČÍK, M. - BECHYNĚ, M. et al. 1982. Rastlinná výroba [Crop production]. Bratislava : Príroda, 1982, 628 p.

UBREŽIOVÁ, I. - HORSKÁ, E. - DOBÁK. 2005. Porovnanie ekonomiky výroby hrachu siateho (Pisum sativum L.) v Českej a Slovenskej republike [Comparison of pea (Pisum sativum L.) production economics in the Czech and the Slovak Republics]. In Agriculture (Pol'nohospodárstvo), vol. 51, no. 2, pp. 68-72.

VANĚK, V. - LOŽEK, O. et al. 2013. Výživa pol'ných a záhradných plodin [Nutrition of field and horticultural crops]. Nitra: Profi Press SK s.r.o., 175 p. ISBN 978-80-970-572-3-7.

Received: October 30, 2013 